\title{
Historical changes in the structure and functioning of the benthic community in the lagoon of Venice
}

\author{
Fabio Pranovi*, Filippo Da Ponte, Patrizia Torricelli \\ Dipartimento di Scienze Ambientali, Università di Ca’ Foscari di Venezia, Castello 2737/B, 30170 Venice, Italy \\ Received 18 April 2007; accepted 6 August 2007 \\ Available online 5 September 2007
}

\begin{abstract}
One of the main challenges in environmental management is how to manage the dynamics of natural environments. In this context, having information about historical changes of the structure of the biological communities could represent a useful tool to improve management strategies, contributing to refine the policy objectives, since it gives reference states with which to compare the present. The Venice lagoon represents an interesting case study, since it is a highly dynamic, but sensitive, environment which requires the adoption of prudent management. In its recent history the lagoon ecosystem has been exposed to different kinds of disturbance, from the discharge of pollutants and nutrients, to the invasion of alien species and the exploitation of its biological resources by using highly impacting fishing gears. The analysis of available data about the macro-benthic community, from 1935 to 2004, allows the description of changes of the community structure over almost 70 years, showing a sharp decrease in its diversity. In order to obtain information about its functioning, it is necessary to know how these changes have affected processes at the community and system level. In shallow water ecosystems, as the control is mainly due to the benthic compartment, variations in the structure of the benthic community can induce modifications in processes at different hierarchical levels. The trophic structure analysis has revealed major changes during the period; from a well-assorted structure in 1935, to an herbivore-detritivore dominated one in the 1990s, and finally to a filter feeder dominated structure during the last decade. This has produced variations in the secondary production and it has induced modifications in the type of the ecosystem control. These changes are discussed in the light of the dynamics of the main driving forces.
\end{abstract}

(C) 2007 Elsevier Ltd. All rights reserved.

Keywords: benthic community; species diversity; biological traits; trophic structure; secondary production; exergy; lagoon of Venice

\section{Introduction}

One of the present main challenges in environmental management is related to the implementation of a holistic approach, in which the ecosystem represents the management unit (Raffaelli, 2006). Ecosystem considerations in a marine scientific and management context have been known for more than a century (e.g. Baird, 1873), but only recently has the ecosystem approach to natural environment and resources management been suggested (World Summit on Sustainable Development in Johannesburg, 2002). It is presently

\footnotetext{
* Corresponding author.

E-mail address: fpranovi@unive.it (F. Pranovi).
}

recommended for adoption by many major policy initiatives, including the EU Water Framework Directive, the Common Fisheries Policy and the European Marine Strategy. The aim of this approach is to ensure that the planning, development and management of the environment will meet social and economic needs, but without jeopardizing the options for future generations to benefit from the full range of goods and services provided by marine ecosystems, i.e. to ensure sustainable development (FAO, 2003). The approach should be taken at the appropriate (large) spatial and temporal scales, recognising the temporal lags between different scales, and that the conservation of ecosystem functioning should be a priority, in order to maintain ecosystem services (CBD, 2004). The research focus needs to be extended, encompassing not 
only the structures of the ecosystem (populations, species, communities, habitats) but also the processes related to the functioning of the ecological systems (production, consumption, respiration, energy flow and cycling), and to seek general relationships among patterns and processes at multiple spatial scales (e.g. Zajac, 1999; Hyrenbach et al., 2000).

Since, it is recognized that human activities, through alterations of ecosystem structures, may impair ecological processes to varying degrees, the gap of knowledge that has to be filled is in the effects of these changes on the ecosystem functioning. Moving towards the assessment of modifications induced in the processes of perturbed ecosystems requires, however, great caution, since processes at the highest hierarchical levels of the ecological systems tend to be conservative, only slowly reacting to external perturbations (Holling et al., 1995).

In shallow water systems, such as coastal lagoons, the benthic compartment plays a crucial role in determining the functioning of the system, controlling the main ecological processes, and changes in its structure could affect the whole ecosystem (Snelgrove et al., 1997; Weslawski et al., 2004; Tenore et al., 2006). By analysing modifications of the lagoon benthic community over time, it could therefore be possible to assess the effects of different ecological drivers on the ecosystems' functioning.

The lagoon of Venice, the widest lagoon in the Mediterranean Sea, like many other coastal areas around the world, during recent decades has been subject to transformations and intense anthropogenic pressure which have deeply modified the natural environment. Four main events can be recognized as strong drivers that are able to directly affect structures and processes in the ecosystem:

1. The modification of the hydrodynamic conditions, related to the excavation of a deep channel in the Central part of the lagoon in the 1960s, which affected the habitat morphology (e.g. salt marshes' distribution, and bottom features, such as texture, grain size, and depth, and erosion rate) (Ravera, 2000);

2. The increase of nutrient load in the 1960s and 1970s, in relation to discharges from the industrial area and the drainage basin, and the urban wastes from the city of Venice (Cossu and De Fraja Frangipane, 1985), with eutrophication and subsequent macro algae blooms and anoxia events recorded in the 1980s (Sfriso et al., 2003);

3. The invasion by the Manila clam, an alien species, intentionally introduced in the lagoon in the middle of the 1980s for aquaculture purposes, and now widespread in the lagoon (Cesari and Pellizzato, 1985; Pranovi et al., 2006); and

4. The mechanical clam harvesting, developed by local fishermen at the beginning of the 1990s to exploit the newformed Manila clam banks (Provincia di Venezia, 2000; Pranovi et al., 2004).

In some ways, therefore, the lagoon has during recent times experienced all the main causes of disturbance which affect coastal areas worldwide, such as eutrophication, morphological change, alien species invasion, and fishing activities. In aquatic environments, among the main causes of anthropogenic disturbance three are recognized as producing the greatest effects: fishing activities, which has produced the collapse of many stocks and the severe threatening of many habitats (NRC, 1995; Botsford et al., 1997; Jackson, 2001; Jackson et al., 2001); alien species, where many of these organisms have profoundly affected the abundance and diversity of native biota in the regions they have invaded (Leppäkoski, 1994); and eutrophication, which has strongly modified the ecosystems' structure, especially in semi-enclosed basins (Caddy, 2000).

The aim of the present study is to evaluate changes in the functioning of the benthic compartment of the Venice lagoon ecosystem, by analysing the modifications in the structure of macro-benthic community, recorded during the last 70 years. These changes will be interpreted in the light of the main ecological drivers, which have affected the lagoon environment during the last decades. This represents a preliminary attempt to have a synoptic view at a large spatial and temporal scale, and to give the opportunity to analyse relationships between diversity and functioning in benthic community, at these scales.

\section{Material and methods}

To reconstruct the time series for the macro-benthic community, different data sources (both published and unpublished) have been considered. The data available are reported in Table 1. The database is composed of 303 taxa, belonging to eight different Phyla, and with 835 replicates. Due to different scientific scopes and the extended period of time considered, data collected are often not perfectly overlapping in terms of sampling gear, sampled area, and the total area surveyed. The time series was characterized by a heterogeneous distribution of samples through time, with an important gap from 1935 to 1988 , only partially filled by 1948 and 1968 data sets. The 1948 and 1968 surveys only reported information about infaunal species. For this reason, these data have been used only in the plots of functioning indices, not for statistical analyses, just to infer something about the processes which had driven the benthic community before the 1988 survey.

As regards the spatial distribution, the different surveys showed different spatial coverage. The surveys carried out in 1935, 1990 and 1999 covered the entire lagoon (all the three basins), whereas the others referred only to one or two basins, resulting in an asymmetric comparison scheme, with some empty cells. The complete time series for each basin is reported in Table 2 (for details about the three basins see Fig. 1).

All recorded species were checked for nomenclature, in order to revise taxonomy and adjustments for attributions were made when necessary (e.g. in case of synonymy). Subsequently all data (both abundance and biomass) were standardized to $\mathrm{m}^{2}$. Wet weight biomasses were transformed to ash-free dry-weight data according to the main taxonomic groups coefficients reported by Tumbiolo and Downing (1994). Since the 
Table 1

List of data sources used to build up the time series for the macro-benthic community and main characteristics of each survey

\begin{tabular}{|c|c|c|c|c|c|c|}
\hline Year & Sampling area & Sampling gear $\left(\mathrm{m}^{2}\right)$ & $\begin{array}{l}\text { Sieve mesh } \\
\text { size }(\mathrm{mm})\end{array}$ & Data collected & Reference & Note \\
\hline 1935 & All three basins & Grab $(0.03)$ & & Abundance & Vatova, 1940 & \\
\hline $1948 / 1968$ & All three basins & Manual corer $(0.04)$ & & Abund./biom. & Giordani Soika and Perin, 1974 & $\begin{array}{l}\text { Data about } \\
\text { infauna }\end{array}$ \\
\hline 1988 & Northern and Central & Grab $(0.1)$ & 1 & & & \\
\hline 1990 & All three basins & Grab (0.04) & 1 & Abund./biom. & MAV, 1992 & \\
\hline 1995 & $\begin{array}{l}\text { Southern, partially } \\
\text { Central }\end{array}$ & Grab (0.16) & 0.5 & Abund./biom. & Pranovi et al., 1999; Sorokin et al., 1999 & \\
\hline 1997 & Partially Southern & Manual corer $(0.04)$ & 1 & Abund./biom. & $\begin{array}{l}\text { Pranovi et al., 2000; Pranovi and } \\
\text { Giovanardi, } 2000\end{array}$ & \\
\hline 1999 & All three basins & Grab $(0.1)$ & 1 & Abund./biom. & Casale et al., 2001; Pranovi et al., 2006 & \\
\hline 2001 & Partially Central & Air lift $(0.2)$ & 1 & Abund./biom. & Pranovi et al., 2004 & \\
\hline 2004 & Partially Northern & Manual corer $(0.05)$ & 0.5 & Abund./biom. & Pranovi, unpublished data & \\
\hline
\end{tabular}

1935 data set reported only abundance data, the biomass values for each species have been calculated by using the mean individual biomass estimated for the same species, in the same basin, for the nearest survey. In the case of a species recorded only in 1935, the biomass value was estimated by using the mean individual biomass of the taxonomically closest species (taking into the account a comparable body size). All these assumptions, in our opinion, could only partially influence results of the functioning indices analysis.

\subsection{Data processing and statistical analysis}

Changes in the macro-benthic community structure have been analysed by applying both multivariate and univariate methods. To describe the temporal trajectories of the community a Multidimensional Scaling (MDS) ordination based on a Bray-Curtis similarity matrix (abundance data, square root transformed) was performed. The differences between years and basins in terms of the benthic assemblage were tested by means of a permutation analysis of variance (PERMANOVA). This non-parametric method, a multivariate analogue to Fisher's $F$-ratio, calculated directly from any symmetric distance or dissimilarity matrix ( $p$-values are obtained using permutations), allows testing of the general multivariate hypothesis of differences in the composition and/or relative abundances of organisms of different species (variables) in samples from different groups (Anderson, 2001; McArdle and Anderson, 2001).

To assess the community diversity, besides the more common diversity indices (such as the specific richness, the total abundance, and the Shannon index), the average taxonomic distinctness $\left(\Delta^{+}\right)$and the variation in taxonomic distinctness $\left(\Lambda^{+}\right)$have been also computed (Clarke and Warwick, 2001).

Table 2

Time series and number of replicates available for each basin of the lagoon

\begin{tabular}{lllllllllll}
\hline & 1935 & $1948^{\mathrm{a}}$ & $1968^{\mathrm{a}}$ & 1988 & 1990 & 1995 & 1997 & 1999 & 2001 & 2004 \\
\hline Northern & 44 & 48 & 48 & 25 & 60 & & & 30 & & 55 \\
Central & 20 & 30 & 30 & 34 & 60 & 11 & & 25 & 10 & \\
Southern & 22 & 26 & 26 & & 120 & 50 & 31 & 30 & & \\
\hline
\end{tabular}

${ }^{a}$ Data about infauna.
The presence of significant differences among years and basins were tested by a one-way PERMANOVA (data $\log (x+1)$ transformed).

The functioning of the benthic community was analysed by adopting several different approaches: Biological Traits Analysis, mean Trophic Level, Secondary Production, Potential Bioturbation, and $\Delta$ Exergy. The biological traits analysis (BTA) uses a series of life history, morphological and behavioural

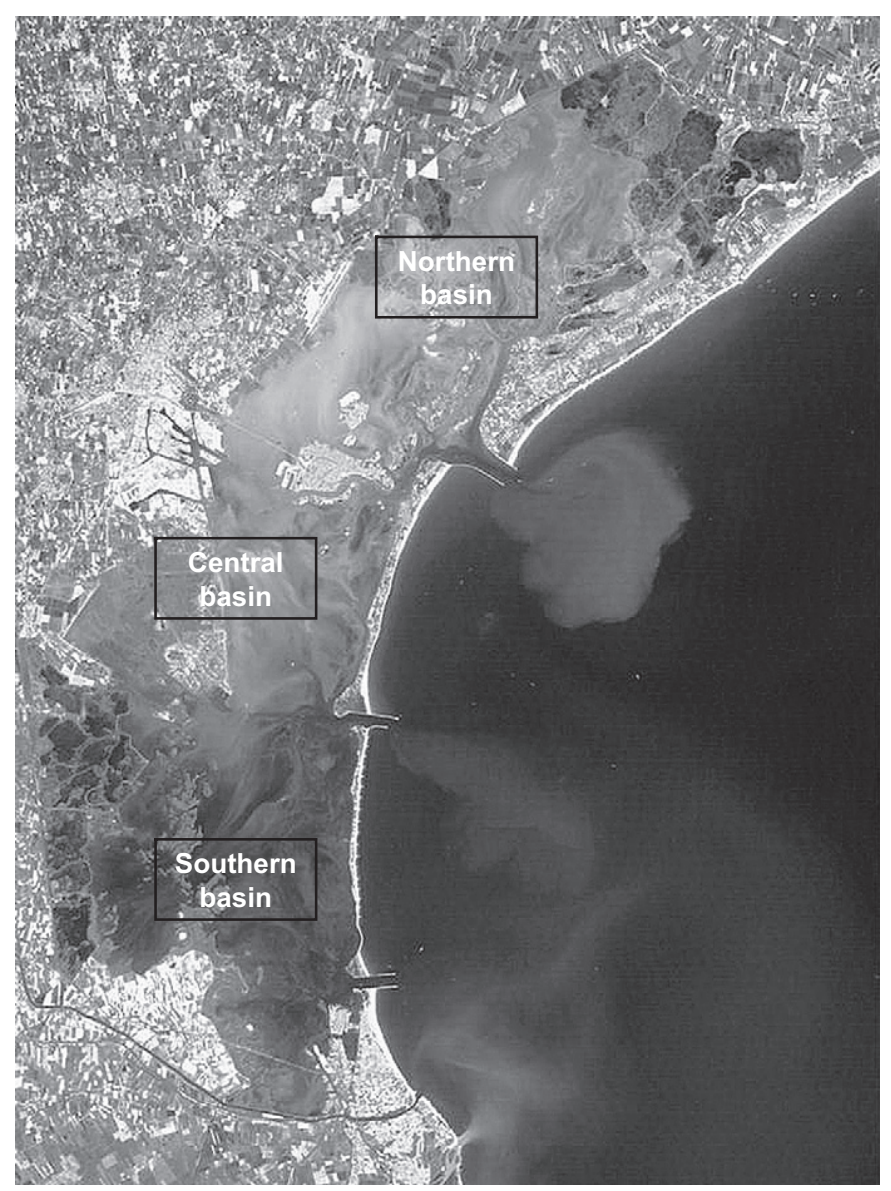

Fig. 1. Location of the three basins of the Venice lagoon (see Table 1 for details). [Picture of the Venetian Lagoon was taken by ASTER, an imaging instrument flying on Terra, a satellite part of NASA's Earth Observing System (EOS)]. 
characteristics of species present in assemblages to indicate aspects of their ecological functioning (Statzner et al., 2001; Bremner et al., 2006). In the present study, a set of seven traits was considered (Table 3). Each taxon in the database was classified for each trait. The frequency of a category was calculated by weighting the sum of the abundance of all taxa exhibiting that category on the total abundance of the sample. The changes in the biological traits composition were analysed by using a PCA (data arcsine transformed).

The community trophic structure was assessed by assigning each species to one of five trophic guilds (filter feeders, detritus feeders, herbivores, predators, and omnivores), using criteria such as the feeding apparatus morphology, the feeding mode and the nature and origin of the food (Fauchauld and Jumars, 1979; Desrosiers et al., 1986, 2000).

To summarize the trophic structure, the mean Trophic Level (mTL) was computed according to the following equation:

$\mathrm{mTL}=\left(\sum_{i}\left(A_{i} \mathrm{TL}_{i}\right)\right) / \sum_{i} A_{i}$

where $A_{i}$ is the abundance of the $i$-species and $\mathrm{TL}_{i}$ is its Trophic Level. The TL of each species was assigned on the basis of its trophic guild, by applying TL values suggested in Pranovi et al. (2003).

Secondary production analysis provides a link between populations and ecosystem, as it represents a measure of

Table 3

List of the biological traits implemented for the BTA and relative categories

\begin{tabular}{|c|c|c|}
\hline Biological trait & Category & Label \\
\hline \multirow{2}{*}{$\begin{array}{l}\text { Relationship with } \\
\text { bottom }\end{array}$} & Epifauna & $\mathrm{E}$ \\
\hline & Infauna & I \\
\hline \multirow[t]{3}{*}{ Body flexibility $\left(^{\circ}\right)$} & $>45$ & $>45$ \\
\hline & $10-15$ & $10-15$ \\
\hline & $<10$ & $<10$ \\
\hline \multirow[t]{3}{*}{ Fragility } & Low & f_low \\
\hline & Medium & f_medium \\
\hline & High & f_high \\
\hline \multirow[t]{4}{*}{ Living habit } & Tube dweller & tube dw \\
\hline & Permanent burrow dweller & $\begin{array}{l}\text { perm burrow } \\
\text { dw }\end{array}$ \\
\hline & Crevice dweller & crevice dw \\
\hline & Free living & free liv \\
\hline \multirow[t]{5}{*}{ Feeding habit } & Filter feeders & moff \\
\hline & Detritus feeders & md \\
\hline & Herbivores & mhd \\
\hline & Mixed feeders & momf \\
\hline & Predators & mop \\
\hline \multirow{3}{*}{$\begin{array}{l}\text { Adult longevity } \\
\text { (years) }\end{array}$} & $<2$ & $<2$ \\
\hline & $2-5$ & $2-5$ \\
\hline & $>5$ & $>5$ \\
\hline \multirow{5}{*}{$\begin{array}{l}\text { Reproductive } \\
\text { technique }\end{array}$} & Asexual & asex \\
\hline & Sexual (broadcast spawner) & sex-brs \\
\hline & Sexual (egg layer/planktonic larvae) & sex-eg-p \\
\hline & Sexual (brooder/planktonic larvae) & sex-bro-p \\
\hline & Sexual (brooder/mini-adults) & sex-bro-mA \\
\hline
\end{tabular}

population's function at the community/ecosystem level (Benke, 1993). In order to investigate the pattern of the benthic production in relation to the different temporal states, the equation proposed by Brey (1990) was applied:

$\log \left(P_{i}\right)=a+b_{1} \log \left(B_{i}\right)+b_{2} \log \left(\bar{W}_{i}\right)$

where the production, $P_{i}$ for $i$-species, is expressed as a function of its biomass, $B_{i}$, and the mean individual weight, $\overline{W_{i}} ; a$, $b_{1}$ and $b_{2}$ are parameters concerning the main benthic taxonomic groups.

The bioturbation, i.e. the biogenic mixing of sediment by benthic organisms, represents a primary determinant of some sediment features (such as the oxygen concentration, the rate of organic matter decomposition, and the regeneration of nutrients) (Pearson, 2001). The bioturbation of the benthic community was estimated according to the method proposed by Solan et al. (2004):

$\mathrm{BP}_{i}=\bar{B}_{i}^{0.5} M_{i} R_{i}$

$\mathrm{BP}_{i}$, the per capita effect, which takes into the account for three biological traits, of $i$ th species, known to influence sediment bioturbation (Pearson, 2001; Bremner et al., 2003; Meysman et al., 2003): the mean body size $\left(B_{i}\right.$, in grams); the propensity to move through the sedimentary matrix $\left(M_{i}\right.$, defined as $1=$ in a fixed tube; $2=$ limited movement, sessile, but not in tube; $3=$ slow movement through sediment; and $4=$ free movement via burrow system); and the method of reworking sediments $\left(R_{i}, 1=\right.$ epifauna that bioturbate at the sediment-water interface; $2=$ superficial modifiers, whose activities are restricted to the first $1-2 \mathrm{~cm}$ of the sediment profile; $3=$ head-down/head-up feeders that actively transport sediment to/from the sediment surface; $4=$ bio-diffusers whose activities result in a constant and random diffusive transport of particles over short distances; and $5=$ regenerators that excavate holes, transferring sediment from depth to the surface). Per capita effect was then multiplied by the species abundance and obtained values summed across species in the sample to estimate the community-level bioturbation potential, $\mathrm{BP}_{\mathrm{c}}$.

The way in which the energy is divided within the different components of the ecosystem represents another opportunity to analyse the functioning of the system. In this context, exergy, which provide a thermodynamic metric that tracked the distance of the ecosystem from thermodynamic equilibrium, could represent a useful measure (Marques and Jorgensen, 2002; Raffaelli, 2006). According to Odum (1969), during their development, self-organizing systems tend to increase biomass, structure, complexity and information, by transforming the free energy, therefore increasing their exergy.

Exergy for biological systems can be estimated by means of the following equation (Jørgensen et al., 1995; Bendoricchio and Jørgensen, 1997):

$\mathrm{Ex}=R T \sum_{i=0}^{N}\left(C_{i} \beta_{i}\right)$ 
where $R$ is the gas constant and $T$ is the absolute temperature, $C_{i}$ is the biomass concentration of the species $(i)$ in the system and $\beta_{i}$ the weighting coefficients expressing the information carried by the $(i$ th) species. The genetic information was suggested as representing the information content embedded in biomass and thus a way of estimating the complexity and organization of organisms. At present, the debate about what measure should be used to represent the information carried by organisms is still open (Jørgensen et al., 1995; Marques et al., 1997; Fonseca et al., 2000; Debeljak, 2002). In the present study, specific genome size ( $C$-value) has been used, even if its use remains questionable since genome size includes the non-coding genes and the repeated DNA that are carried unused information (Bendoricchio and Jørgensen, 1997; Debeljak, 2002; Gregory, 2005).

In its original formulation, exergy is calculated as the distance from a reference state (Wall, 1977; Svirezhev, 2000) and the "primitive inorganic soup" was suggested as reference for biological systems (Jørgensen et al., 1995). For real ecosystems, however, a measure of local exergy (sensu Wall, 1977), defined in relation to a real reference state and/or to the surrounding environment appears to be more appropriate (Libralato et al., 2005). In the present study, the 1935 samples were used as reference and $\Delta$ Exergy calculated as difference form those values.

A one-way PERMANOVA was preformed to test the differences among years and basins for the functioning indices. To test the relationship between diversity (in terms of specific richness) and functioning indices, a Spearman's rank correlation analysis was applied. To verify the presence of a spatial scale effect, the Spearman's test was carried out both on the matrix of all replicates ( $\alpha$ diversity) and on the matrix of mean values per basin ( $\gamma$ diversity). The Multivariate and PERMANOVA analyses were performed by using Primer 6 and PERMANOVA + software package and the Spearman's rank correlation analysis by using STATISTICA.

\section{Results}

The MDS ordination shows the temporal trajectory of the macro-benthic community for each basin, determined by changes in the assemblage composition (Fig. 2). The homogeneity of the three basins decreases during the time, as the ecological drivers acting on the lagoon become more localized. In the last part of the series, samples were more spread as confirmed by the MultiDispersion Index (MDI) and the similarity analysis, preformed by SIMPER (Table 4). Moreover, the Southern basin shows a quite different trajectory in comparison with the other two basins.

To test the hypothesis that the trajectory shown by the Southern basin was due to it being more conservative ('closed') than the others, the index of multivariate seriation (IMS, Clarke et al., 1993; Warwick et al., 2002) was applied. This index performs a Spearman's rank correlation test between the observed similarity matrix and the matrix that would result from the inter-point distances of the same number of samples equally spaced along a straight line. The results of

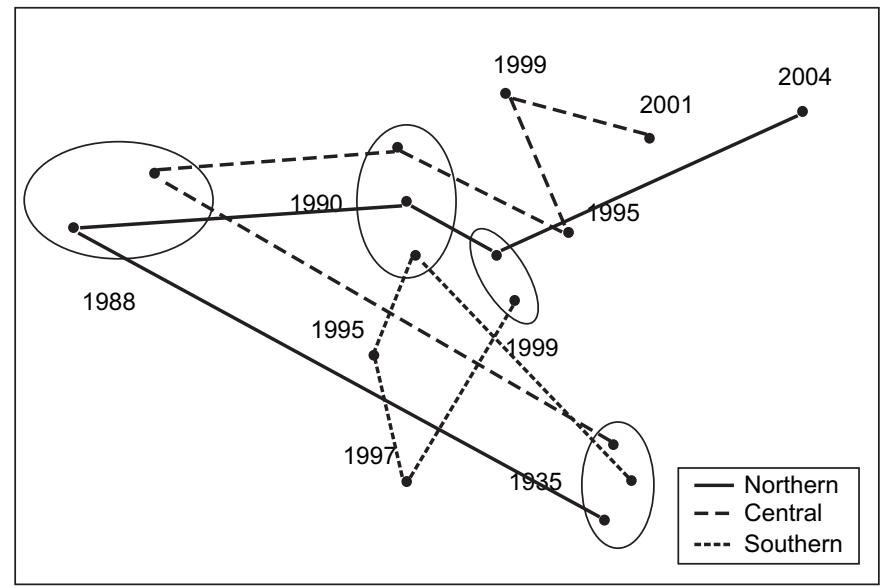

Fig. 2. MDS on specific composition data (mean values per basin per date); Bray-Curtis similarity matrix on data transformed by square root.

the test confirm the hypothesis, being statistically significant for the Southern series $(\mathrm{Rho}=0.64)$ and not significant for the other two series $(-0.1$ and -0.15 , for the Central and the Northern basin, respectively).

The one-way PERMANOVA highlights significant differences among years and basins, confirming the changes in the community structure during the time, and the presence of different patterns in the three basins (for the results of this analysis, see Appendix A).

\subsection{Diversity indices}

In terms of the specific richness the comparison between 1935 and the rest of the series highlights a significant loss in diversity (Fig. 3). In particular, in 1935, 16 exclusive species (three echinoderms, two bivalves, five polychaetes, and five crustaceans) were recorded and other 29 species showed a higher abundance.

The total abundance showed a quite different pattern with the highest values (more than 2000-3000 individuals per $\mathrm{m}^{2}$ ) recorded in 1988 (Fig. 4). The values then sharply declined and increased only at the end of the series, in the Central basin.

All this directly influences the pattern of the Shannon index (Fig. 5). The average taxonomic distinctness $\left(\Delta^{+}\right)$and its variation $\left(\Lambda^{+}\right)$give the opportunity to look at diversity from a taxonomic perspective (Fig. 6). The 1935 samples showed the highest diversity values (and the lowest variation). Interestingly, all samples collected in the Southern basin showed values comparable to the 1935 ones, whereas the lowest values

Table 4

MultiDispersion Index (MDI), percentage of similarity among samples and number of species significantly contributing to similarity

\begin{tabular}{lrll}
\hline & MDI & Similarity $(\%)$ & No. sign. species \\
\hline 1935 & 0364 & 63 & 16 \\
1990 & 097 & 44 & 9 \\
1988 & 1091 & 51 & 9 \\
1999 & 1636 & 22 & 4 \\
\hline
\end{tabular}




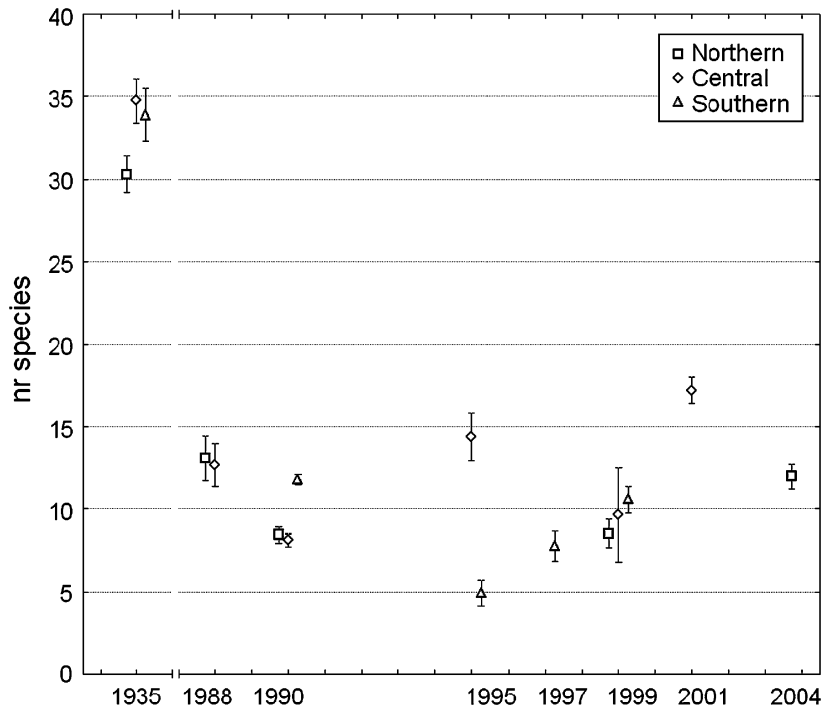

Fig. 3. Specific richness.

were recorded in 1988 and in the Central basin in 1999. The PERMANOVA test highlighted, for almost all diversity indices, significant differences among years for each basin and among basins (for the results of this analysis, see Appendix A).

\subsection{Functional indices}

The PCA results based on the biological traits allow the distinguishing, even if only in the context of a sort of gradient, three groups of stations, characterized by different traits composition (Fig. 7): a first group, composed by the samples collected in 1988, characterized by sessile species, tube dweller, with a high/medium fragility, and belonging to the detritus feeders trophic group; a second group, mainly represented by the samples collected in 1935 and some samples of the Southern basin, characterized by epifauna species, free living,

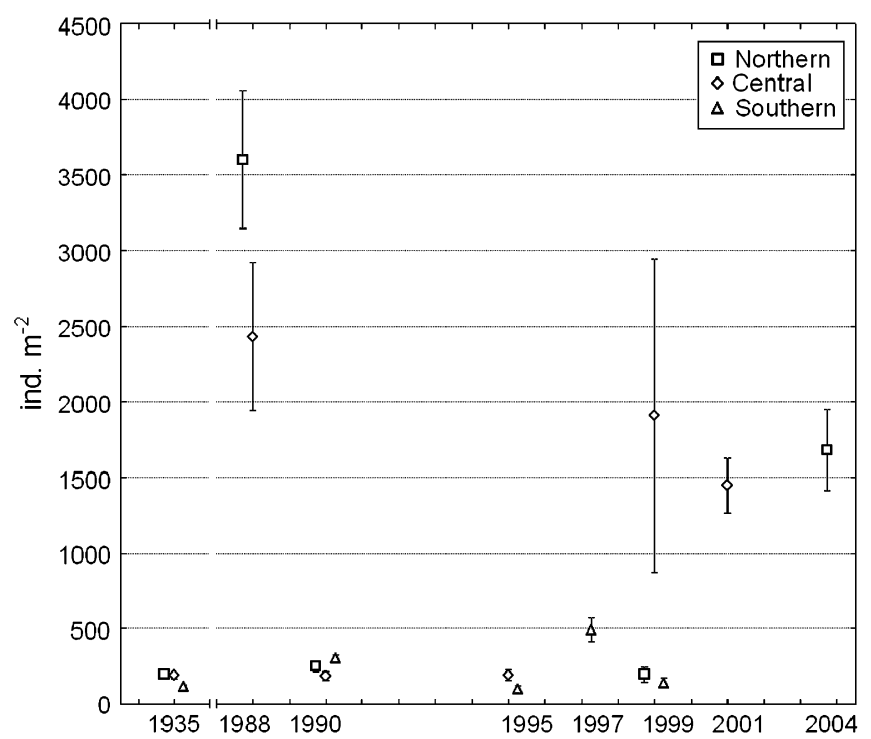

Fig. 4. Total abundance.

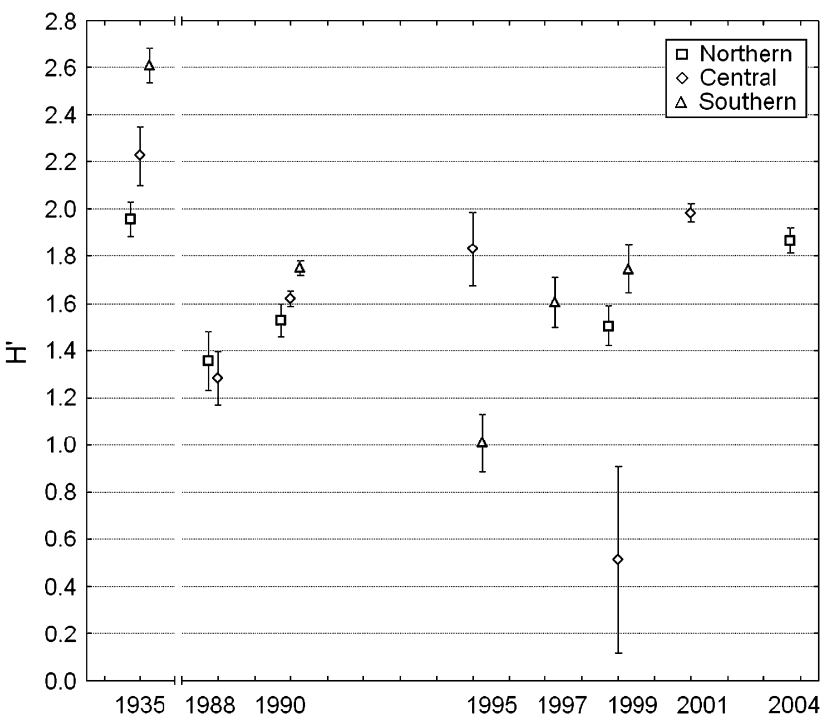

Fig. 5. Shannon index.

with a medium fragility, and belonging to the mixed feeders trophic group; and a third group, well represented by the samples collected in 1999 in the Central basin, characterized by infaunal species, burrow dweller, with a low fragility due to the presence of an external shell, and belonging to the filter feeders trophic group.

According to life history traits, the 1988 samples are characterized by short life-span species ( $<2$ years), adopting the 'egg layer/brooder/planktonic larvae' reproductive strategy; whereas the 1995-1999 Central basin samples are characterized by long life-span species ( $>5$ years), adopting the 'broadcast spawner' reproductive technique. Finally, the group represented by the 1935 samples is characterized by medium life-span species, adopting the 'egg layer/brooder/mini-adults' reproductive technique.

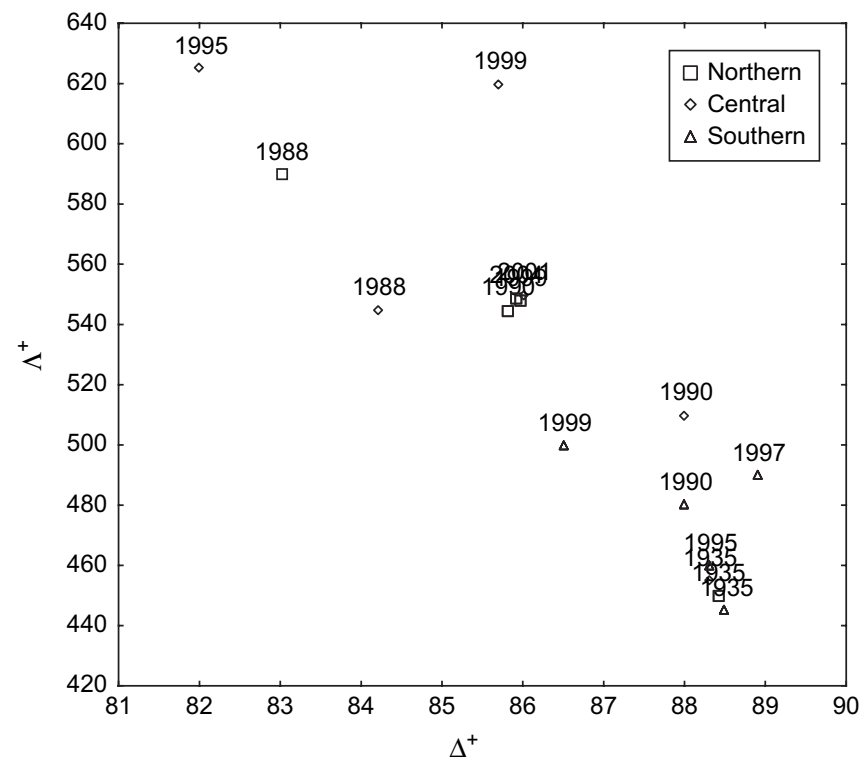

Fig. 6. Average taxonomic distinctness $\left(\Delta^{+}\right)$vs variation in taxonomic distinctness $\left(\Lambda^{+}\right)$plot. 


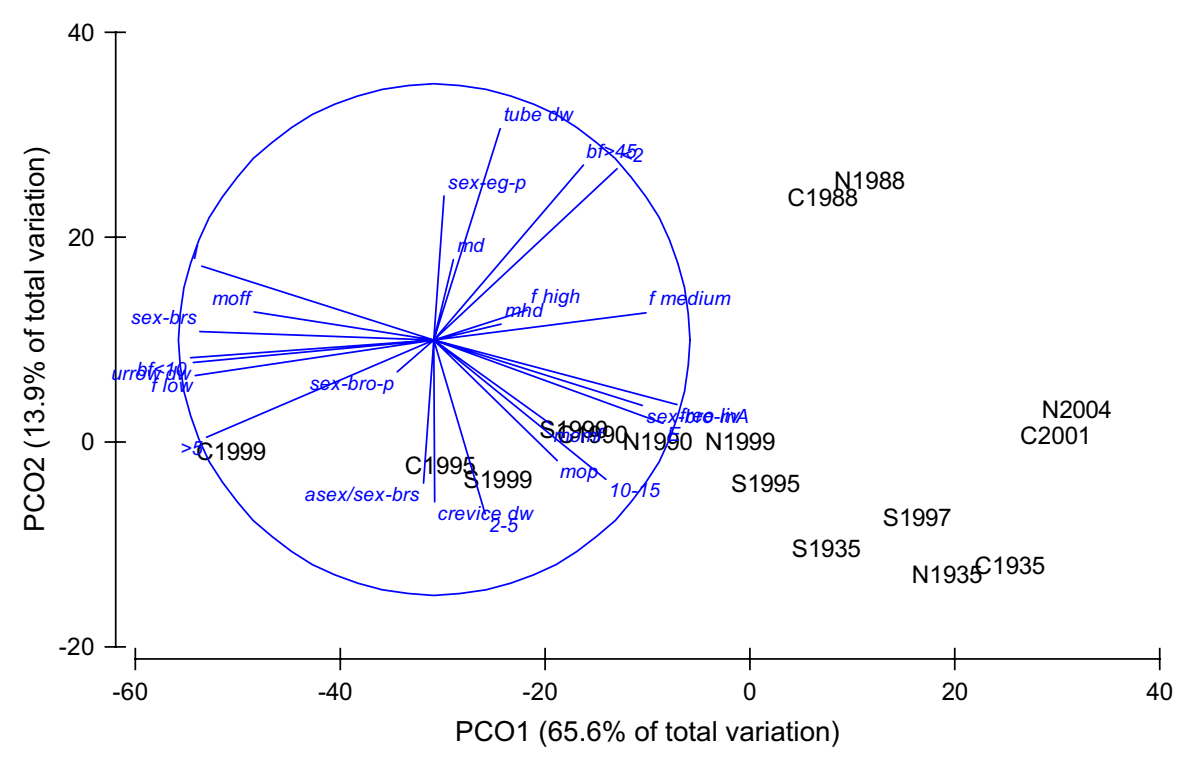

Fig. 7. PCA on the biological traits analysis; data as frequency, transformed according arcsine transformation.

In terms of trophic structure, the trophic groups' distribution in 1935 highlighted the high incidence of herbivores characterizing the Central basin (Fig. 8). In term of temporal dynamic, all the three basins at the end of 1980s to beginning of the 1990s showed an increase of detritus feeders. During the following decades, the benthic community in the three basins seemed to follow different trajectories. The mixed feeders become the dominant group in the Northern basin, whereas in the Central basin the filter feeders came to be dominant (e.g. in 1999). Finally, the Southern basin showed an articulated structure, with herbivores which play a significant role during the 1990s. This pattern is confirmed by the mean Trophic Level index which showed a decrease from 1935 to 1988, followed by a gradual increase, culminating at the end of the series (Fig. 9). The PERMANOVA analysis highlighted that the trend is statistically significant in term of years for the Northern and the Southern basin and for the comparison among the basins (for the results of this analysis, see Appendix A).

For both the Secondary Production and the Biogenic Mixing Index, estimates obtained by using samples from surveys carried out in 1948 and 1968 were added to the time series, partially filling the gap between 1935 and 1988. The temporal pattern for the Secondary Production is shown in Fig. 10. A gradual increase, culminating in 1988, during the phase of the macro algae blooms, was recorded, followed by a sharp drop in 1990, in all the three basins. A second peak was recorded in 1999, only in the Central basin. The PERMANOVA analysis highlighted that the trend is statistically significant both for years in each basin and for the comparison among the basins (for the results of this analysis, see Appendix A). The values recorded in 1988 were significantly higher than the others.

The Biogenic Mixing Index temporal trend is shown in Fig. 11. The pattern, statistically significant both for years in each basin and for the comparison among the basins (for the results of this analysis, see Appendix A), is similar to that recorded for the Secondary Production with an increase of the values from 1935 to 1988 , then a sharp decrease. A second peak was recorded in the Central basin in 1999.

The temporal trend of $\Delta$ Exergy is shown in Fig. 12. Almost all values of the time series were found to be higher than those of 1935 (all $\Delta$ values are positive, except the Northern basin in 1948). A gradual increase of values from 1948 to 1988, both in the Northern and Central basins, then a sharp decrease was recorded. In the final part of the series, the Southern basin showed an increase with a peak recorded in 1999. The PERMANOVA analysis highlighted that the trend is statistically significant both for years in each basin and for the comparison among the basins (for the results of this analysis, see Appendix A).

\section{Discussion}

Coastal lagoons represent distinct environments characterized by a reduced diversity, due to the selective environmental conditions, and by a high productivity, due to the shallowness and the nutrient enrichment. Moreover, they are subjected to dynamic changes, being ephemeral environments destined to transform ultimately into dry land due to the action of the same forces that created them (Ravera, 2000).

The lagoon of Venice represents an exceptional case study in relation to the many challenges it offers in terms of management strategies to be adopted. It is the result of a co-evolution with human presence, which has completely modified the natural trend: the present evolution of the lagoon is more towards a marine bay more than to dry land.

The analysis of the macro-benthic community time series allows us to track the changes in the benthic assemblage, highlighting both spatial and temporal differences. In spatial terms, different trajectories were recognized for the three basins of the lagoon, with the Southern one showing the more conservative pattern. This could be related to the historical presence of consolidated seagrass meadows (Caniglia et al., 1992), whose importance in maintaining biodiversity and stabilising marine 

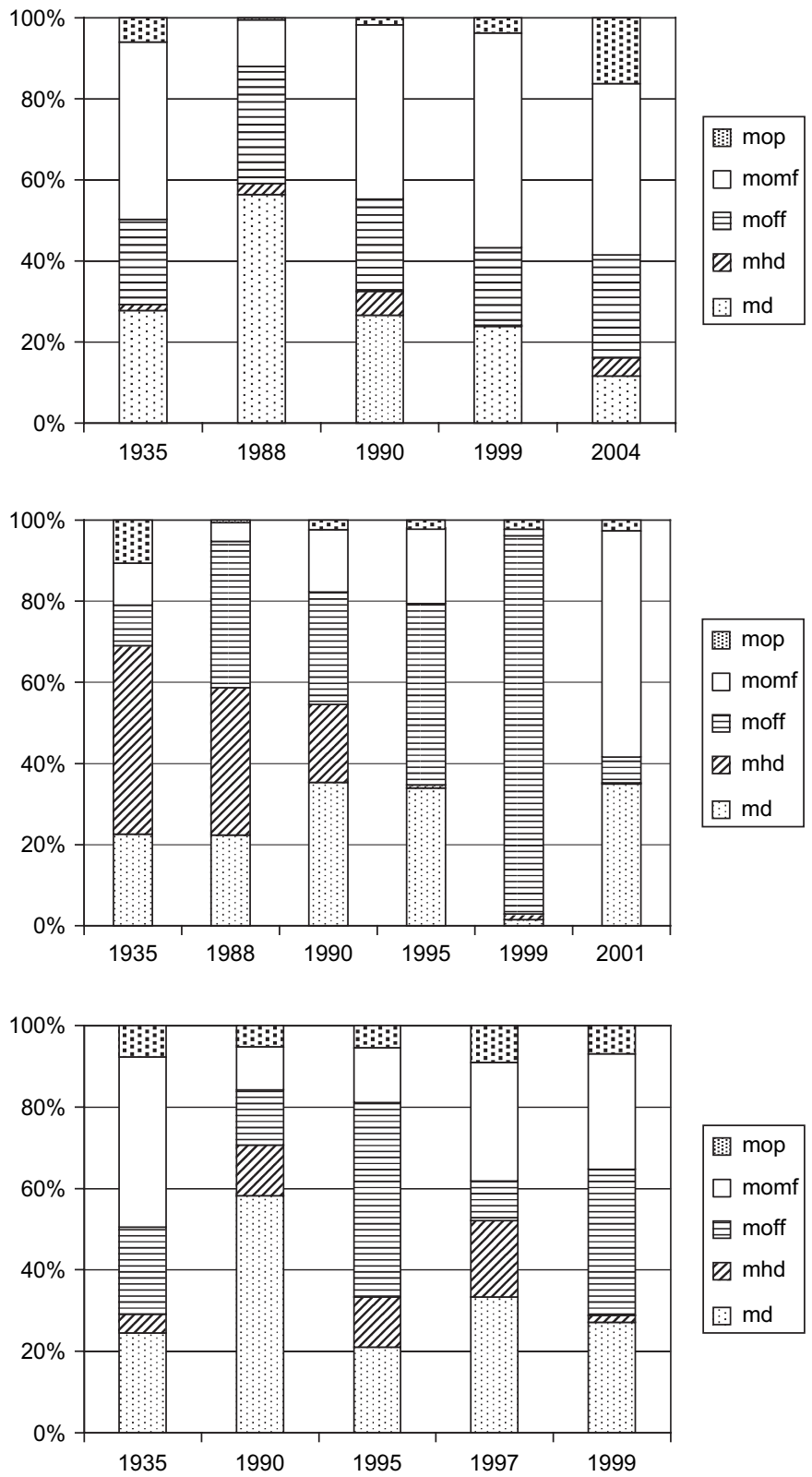

Fig. 8. Trophic structure in the Northern, Central and Southern basin, respectively; $\quad m d=$ detritus feeders, $\quad$ mhd $=$ herbivores; moff $=$ filter feeders; momf $=$ mixed feeders; mop $=$ predators.

ecosystems is well recognized (Duffy, 2006). In terms of temporal variations, it is worthy to note that the differences between the basins seem to increase, e.g. the samples collected in 1999 in the three basins were quite dispersed. This can be explained with the fact that in 1999 the main ecological driver (namely, the massive presence of Manila clams and the resultant heavy exploitation pressure) was not equally distributed over the lagoon, whereas previously the drivers were more uniformly distributed.

\subsection{The diversity-functioning relationship}

The empirical evidence about the diversity-functioning relationship in macro-benthic communities indicates that changes

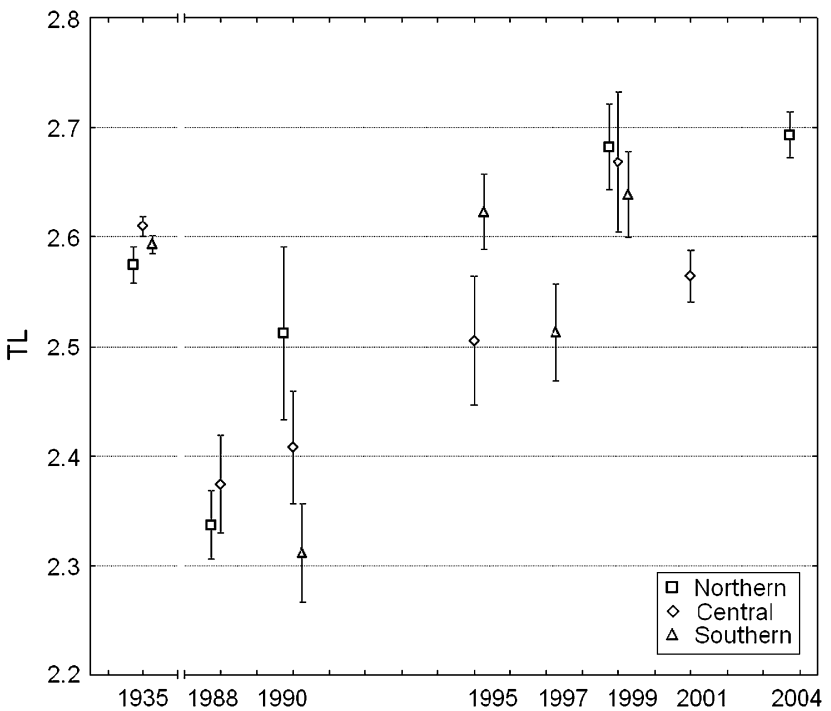

Fig. 9. Temporal trend of the mean Trophic Level (mTL).

in the specific richness have highly variable effects on ecosystem functioning in terms of the magnitude and direction of responses (Covich et al., 2004). In this context, the time series of the Venice lagoon represents a good basis for analysing aspects of this relationship on a wide spatial and temporal scale, incorporating multi-trophic-level interactions and considering a wider range of species that differ in size, biomass, and life history traits.

The results obtained highlight the presence of an idiosyncratic relationship between diversity and system efficiency. Indeed, the low values of diversity recorded in 1988 and 1999 corresponded to high values in terms of functioning indices, such as the Secondary Production, Biogenic Mixing Index and $\Delta$ Exergy. It seems to raise, moreover, the importance of the scale in analysing biodiversity-functioning relationship

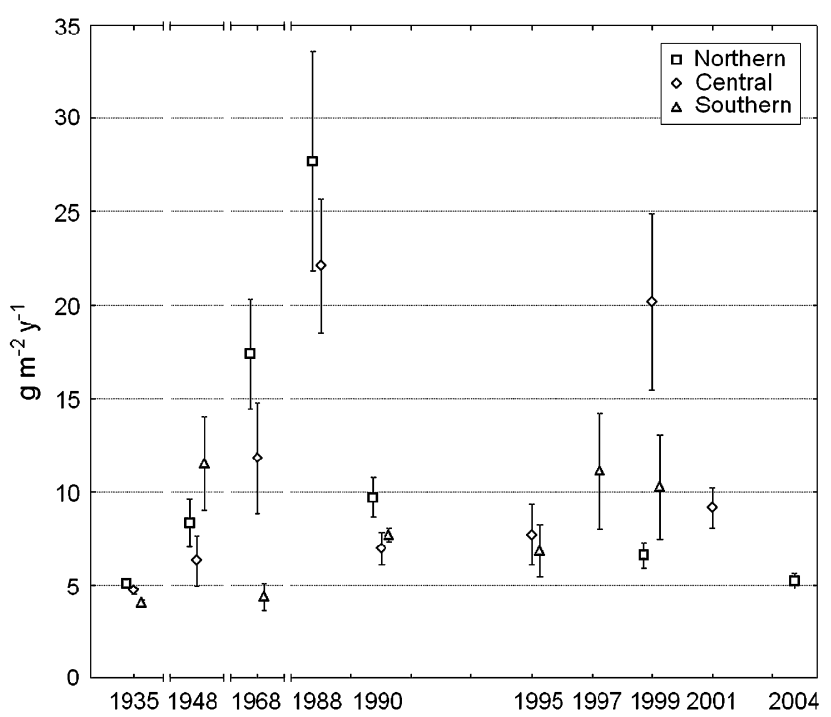

Fig. 10. Temporal trend of the Secondary Production; in order to better describe the temporal pattern data about 1948 and 1948 surveys have been considered. 


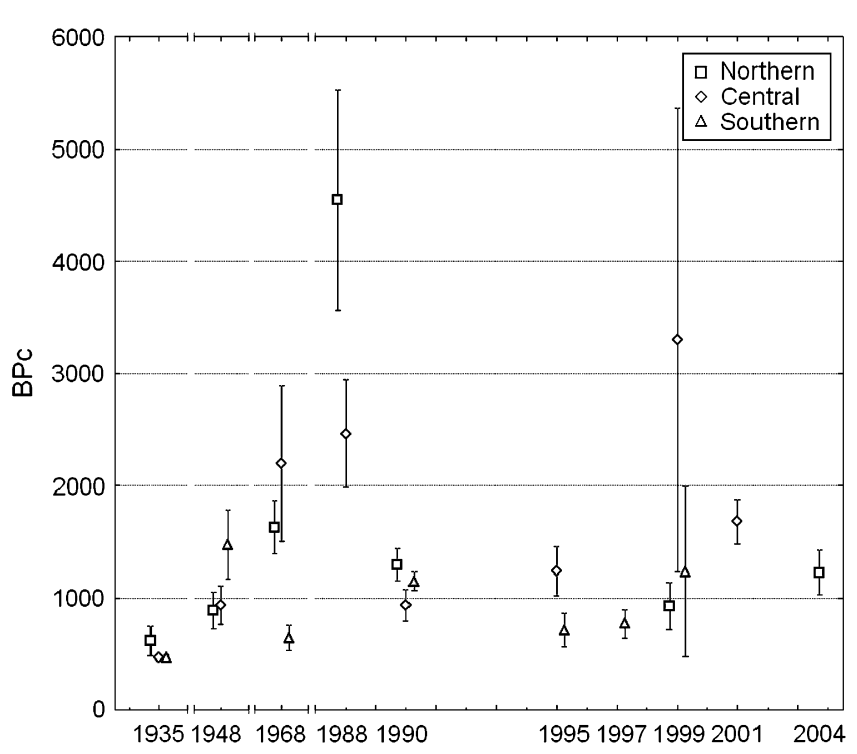

Fig. 11. Temporal trend of the Biogenic Mixing index; in order to better describe the temporal pattern data about 1948 and 1948 surveys have been considered.

(Raffaelli, 2006). By using the $\alpha$ diversity measure (which takes into account variations at the station level), there is a significant correlation (Spearman's test) between diversity and functioning indices; whereas, by using the $\gamma$ diversity measure (which takes into account variations at the basin level) no significant correlation was recorded, for all the functioning indices (Table 5). This could be related to the fact that, in the real communities, the provision of ecosystem processes will depend not only upon the number of species, but also on the relative contribution of dominant and minor species (Emmerson et al., 2001; Solan et al., 2004) and the environmental context (Biles et al., 2003). Ruesink et al. (2006) have recently

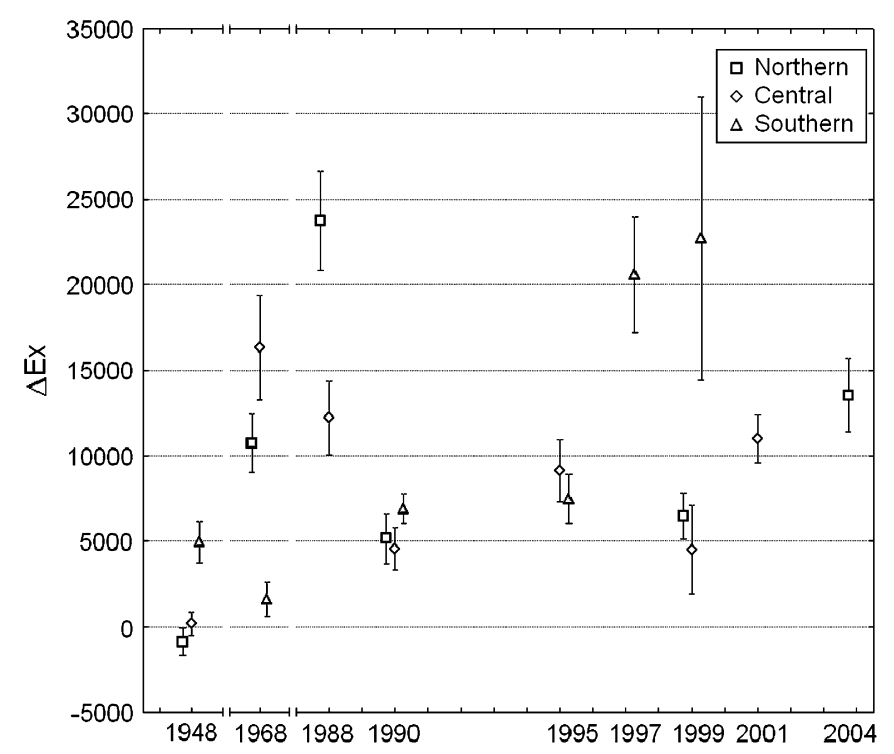

Fig. 12. Temporal trend of the $\Delta$ Exergy; reported values are the differences with the 1935 values; in order to better describe the temporal pattern data about 1948 and 1948 surveys have been considered.
Table 5

Spearman's correlation between specific richness (in terms of $\alpha$ and $\gamma$ diversity) and functional indices

\begin{tabular}{|c|c|c|c|c|c|}
\hline $\begin{array}{l}\text { Specific } \\
\text { richness }\end{array}$ & $\begin{array}{l}\text { Functioning } \\
\text { index }\end{array}$ & $N$ & Spearman's $R$ & $t(n-2)$ & $p$ \\
\hline \multirow[t]{3}{*}{$\alpha$ diversity } & Secondary Production & 683 & 0.334 & 9.256 & 0.001 \\
\hline & Biogenic mixing index & 697 & 0.363 & 10.277 & 0.001 \\
\hline & Exergy & 497 & 0.197 & 4.489 & 0.001 \\
\hline \multirow[t]{3}{*}{$\gamma$ diversity } & Secondary Production & 22 & -0.288 & -1.345 & ns \\
\hline & Biogenic mixing index & 22 & -0.094 & -0.426 & $\mathrm{~ns}$ \\
\hline & Exergy & 22 & -0.187 & -0.712 & ns \\
\hline
\end{tabular}

suggested that, in some cases, the successful invasion by an alien species can enhance ecological processes (e.g. the productivity), as in the Venice lagoon for the Manila clam in 1999.

\subsection{Benthic community and ecological drivers}

A common feature of each biological assemblage is the capacity to structure itself in relation to the main energy source, optimizing the production (Holling et al., 1995). This capacity is enhanced in lagoon environments where biological communities are adapted to changing conditions, both cycling (such as tides and seasons) and directional changes (due to the natural developmental trend) by natural conditions.

By analysing the benthic community in the Venice lagoon, during the last 70 years it has been possible to recognize at least three different stages, the first being represented by the community described for 1935 (a 'pristine' state, with no or little anthropogenic pressures), the second one recorded in 1988 at the end of the eutrophication phase (dominated by benthic primary producers), and finally the third one, recorded in 1999, dominated by filter feeders (namely the Manila clam) with a community selected also by the deep disturbance produced by the mechanical clam harvesting. The main features of these stages are summarized in Table 6.

In the first stage, the resultant community was highly diversified, both in terms of the number of species and trophic structure, with an important contribution of epifauna species, characterized by high mobility, but with low values of Secondary Production and Exergy.

During the 1950s and 1960s, the fast development of the industrial area, jointly with the discharges both from the city and the drainage basin, drove the lagoon towards a eutrophic state (Pastres et al., 2004). Comparing data collected in 1948 and 1968, Giordani Soika and Perin (1974) reported a significant increase of average nutrient contents in the bottom sediments (3 times for Nitrogen and 10 times for Phosphorous). The end of the nutrient enrichment phase was characterized by macro algae blooms (with biomass of $20 \mathrm{~kg} \mathrm{~m}^{-2}$ and a gross primary production higher than $130 \mathrm{~kg} \mathrm{~m}^{-2} \mathrm{y}^{-1}$ ) and consequent anoxia events (Sfriso et al., 2003). This meant that a great amount of energy, normally flowing through the ecosystem was confined by the huge algal biomass, becoming less available for the other components, as confirmed also by the 
Table 6

Main features of the benthic community referred to the three main ecological stages

\begin{tabular}{|c|c|c|}
\hline 1935 & 1988 & 1999 \\
\hline $\begin{array}{c}\text { Low anthropogenic } \\
\text { pressures }\end{array}$ & Eutrophication & Manila clam and its exploitation \\
\hline High diversity & Low diversity & Low diversity \\
\hline Low biomass & $\begin{array}{l}\text { High biomass/ } \\
\text { productivity }\end{array}$ & High biomass/productivity \\
\hline $\begin{array}{l}\text { Diversified trophic } \\
\text { structure }\end{array}$ & $\begin{array}{l}\text { Simplified trophic } \\
\text { structure }\end{array}$ & Simplified trophic structure \\
\hline High mTL & Low mTL & High trophic level \\
\hline Low exergy & High exergy & High exergy \\
\hline \multicolumn{3}{|l|}{ Biological traits } \\
\hline Epifaunal species & & Infaunal species \\
\hline Free living & Tube dweller & Burrower \\
\hline High mobility & Medium mobility & Low mobility \\
\hline Medium fragility & High fragility & Low fragility \\
\hline Mixed feeders & Detritus feeders & Filter feeders \\
\hline $\begin{array}{l}\text { Medium life } \\
\quad(2-5 \text { years })\end{array}$ & $\begin{array}{l}\text { Short life } \\
(<2 \text { years })\end{array}$ & $\begin{array}{l}\text { Long life } \\
(>5 \text { years })\end{array}$ \\
\hline Brooder/mini-adults & $\begin{array}{l}\text { Egg layer/planktonic } \\
\text { larvae }\end{array}$ & Broadcast spawner \\
\hline
\end{tabular}

extremely low value (about 5\%) of the ecosystem transfer efficiency calculated for this period (Libralato et al., 2004). Moreover, the decomposition processes due to anoxia, increased the organic matter flowing directly towards the bottom sediments.

The changes in the trophic structure, with a shift towards detritus feeders and herbivores, have to be viewed as an adaptation, which allow the functioning optimization of the benthic compartment.

According to Cloern (2001), this can be interpreted as a sign of stress, which could expose the ecosystem to nonnative species invasion. A particular state of the recipient region, such as altered ecological, biological, chemical or physical state, could indeed produce a sort of 'invasion window', increasing the system's susceptibility to invasion (Carlton, 1996). The lagoon of Venice, in that period from the end of the 1980s to the beginning of the 1990s did experience the most successful invasion by an alien species, the Manila clam, which introduced in the middle of 1980 s, rapidly spread throughout the whole lagoon, becoming the most abundant bivalve species and supporting 40,000 tons per year of fisheries yield. As a consequence, the presence of Ruditapes philippinarum, and the effects of its exploitation, became the dominant ecological factor, deeply affecting the functioning of the lagoon ecosystem (Pranovi et al., 2006).

All this coincided with the third stage, featured by a shift towards infaunal species, characterized by a low mobility and a low fragility. At the same time, the community showed a high secondary production, mainly enhanced by the Manila clam, but a low maturity, as confirmed by the $\Delta$ Exergy values, mainly in the Central basin.

Both the last two ecological stages were characterized by the over-dominance of a single species (Ulva rigida and Ruditapes philippinarum, respectively) producing the phenomenon described by Bishop et al. (2007) as 'trophic cul-de-sac'. A great amount of energy, which normally flows through the system was now stored in a scarcely accessible compartment resulting in a sharp reduction of the system's resilience and conversely an increase of its resistance.

\subsection{The ecological stages and the adaptive cycle}

The ecological transitions described here can be schematised by using, as theoretical framework, the four phases (exploitation, conservation, release, reorganization) of the 'adaptive cycle' (Holling, 1986; Holling et al., 1995).

The first part of the cycle (from exploitation to conservation) corresponds to the classic ecosystem succession, being the 'exploitation phase' dominated by opportunistic species ( $r$-strategists), and the 'conservation phase' characterized by the accumulation and storage of energy and material (see Marques et al., 2003).

For the lagoon ecosystem, after that we can imagine as a stable phase (exemplified by the 1935 stage), the first two phases of the Holling cycle could be associated to the growing due to the eutrophication (during the 1970s) and the successive storage of energy and material in the huge macro algae biomass (during the 1980s).

The following phases of the cycle are the 'release', in which tightly bound energy and material are released because an external disturbance or a crisis, and the 'reorganization', when species and processes in the system reorganize to start another lap in the renewal cycle. The transition between these two phases is highlighted as a critical point, since the ecosystem may 'flip' into a new stability domain. For the lagoon ecosystem, the release phase could be recognized in the collapse of macro algae biomass. During the reorganization phase a flip, as described in the theory, was observed in relation to the invasion of Manila clam, which drove the system towards a new ecological equilibrium.

The adaptive cycle has therefore proved to be a conceptual model that is useful to interpret the changes of macro-benthic community that have been recorded in the lagoon of Venice during the last decades.

It may be concluded that the time series analysis of the macro-benthic community has allowed a description of the changes that have occurred in the benthic assemblage and the related modifications in the system functioning. The three basins of the lagoon have shown different temporal trajectories, with the Southern one less prone to change, or, in other terms, more resilient.

In the context of the environmental management of the Venice lagoon, the results obtained results raise a serious question about the identification of the reference state to be used for the EcoQ objectives implementation, since no clear diversity - functioning relationship has been defined. The two more recent stages recognized for the macro-benthic community, although poor in terms of diversity, were found to be good in terms of functioning (e.g. for the Secondary Production and the Biogenic Mixing Index).

Finally Exergy has been confirmed as an index able to summarize aspects of functioning different from those caught by 
other indices, and so is potentially useful in a management context. For the last part of the time series, the Exergy analysis suggested the presence of better conditions in the Southern basin, which in 1999 was less affected by the presence of the Manila clam and less impacted by the mechanical clam harvesting (Pranovi et al., 2006).

\section{Acknowledgements}

We thank Dr. Jason Link for the useful discussions phase and the constructive comments on the manuscript, and the anonymous referees that contributed to significantly improve the paper. This work was supported by a CNR grant to F. Pranovi, in the context of the Short Term Mobility Program 06.

\section{Appendix A. Supplementary data}

Supplementary data associated with this article can be found, in the online version, at doi:10.1016/j.ecss.2007.08.006.

\section{References}

Anderson, M.J., 2001. A new method for non-parametric multivariate analysis of variance. Austral Ecology 26, 32-46.

Baird, S.F., 1873. Report on the condition of the sea fisheries of the south coast of New England in 1871 and 1872. In: Report of the United States Fish Commission, vol. 1. GPO, Washington, DC.

Bendoricchio, G., Jørgensen, S.E., 1997. Exergy as goal function of ecosystem dynamics. Ecological Modelling 102, 5-15.

Benke, A.C., 1993. Concepts and patters of invertebrate production in running waters. Internationale Vereinigung fur theoretische und angewandte Limnologie, Verhandlungen 25, 15-38.

Biles, C.L., Solan, M., Isaksson, I., Paterson, D.M., Emes, C., Raffaelli, D.G., 2003. Flow modifies the effect of biodiversity on ecosystem functioning: an in situ study of estuarine sediments. Journal of Experimental Marine Biology and Ecology 285-286, 165-177.

Bishop, M.J., Kelaher, B.P., Alquezar, R., York, P.H., Ralph, P.J., Skilbeck, C.G., 2007. Trophic cul-de-sac, Pyrazus ebeninus, limits trophic transfer through an estuarine detritus-based food web. Oikos 116, 427-438.

Botsford, W., Castilla, J.C., Peterson, C.H., 1997. The management of fisheries and marine ecosystems. Science 277, 509-515.

Brey, T., 1990. Estimating productivity of macro-benthic invertebrates from biomass and mean individual weight. Meeresforschung 32, 329-343.

Bremner, J., Rogers, S.I., Frid, C.L.J., 2003. Assessing functional diversity in marine benthic ecosystems: a comparison of approaches. Marine Ecology Progress Series 254, 11-25.

Bremner, J., Rogers, S.I., Frid, C.L.J., 2006. Methods for describing ecological functioning of marine benthic assemblages using biological traits analysis (BTA). Ecological Indicators 6, 609-622.

CBD (Convention on Biological Diversity), 2004. Available from: www.biodiv. org/programmes/cross-cutting/ecosystem/.

Caddy, J.F., 2000. Marine catchment basin effects versus impacts of fisheries on semi-enclosed seas. ICES Journal of Marine Science 57, 628-640.

Caniglia, G., Borella, S., Curiel, D., Nascimbeni, P., Paloschi, F., Rispondo, A., Scarton, F., Tagliapietra, D., Zanella, L., 1992. Distribuzione delle fanerogame marine Zostera marina L., Zostera noltii Hornem., Cymodocea nodosa (Ucria) Ascherson in laguna di Venezia. Lavori Società Veneziana di Scienze Naturali 17, 137-150.

Carlton, J.T., 1996. Pattern, process and prediction in marine invasion ecology. Biological Conservation 78, 97-106.

Casale, M., Giovanardi, O., Grimm, F., Orel, G., Pessa, G., 2001. Abundance and distribution of most important clams in the lagoon of Venice during summer
1999, with particular reference to Tapes philippinarum (Adams \& Reeve, 1850). Biologia Marina Mediterranea 8, 413-423.

Cesari, P., Pellizzato, M., 1985. Molluschi pervenuti in Laguna di Venezia per apporti volontari o casuali. Acclimatazione di Saccostrea commercialis (Iredale \& Roughely, 1933) e di Ruditapes philippinarum (Adams \& Reeve, 1850). Bollettino Malacologico 21, 237-274.

Clarke, K.R., Warwick, R.M., 2001. A further biodiversity index applicable to species lists: variation in taxonomic distinctness. Marine Ecology Progress Series 216, 265-278.

Clarke, K.R., Warwick, R.M., Brown, B.E., 1993. An index showing breakdown of seriation, related to disturbance, in a coral reef assemblage. Marine Ecology Progress Series 102, 153-160.

Cloern, J.E., 2001. Our evolving conceptual model of the coastal eutrophication problem. Marine Ecology Progress Series 210, 223-253.

Cossu, R., De Fraja Frangipane, E., 1985. Stato delle conoscenze sull'inquinamento della laguna di Venezia. vols. I-IV. Ministro dei Lavori Pubblici - Magistrato alle acque, Consorzio Venezia Nuova, Venice, Italy, 438 pp.

Covich, A.P., Austen, M.C., Bärlocher, F., Chauvet, E., Cardinale, B.J., Biles, C.L., Inchausti, P., Dangles, O., Solan, M., Gessner, M.O., Statzner, B., Moss, B., 2004. The role of biodiversity in the functioning of freshwater and marine benthic ecosystems. BioScience 54, 767-775.

Debeljak, M., 2002. Applicability of genome size in exergy calculation. Ecological Modelling 152, 103-107.

Desrosiers, G., Bellan-Santini, D., Brêthes, J.C., 1986. Organisation trophique de quatre peuplements de substrats rocheux selon un gradient de polution industrielle (Golfe de Fos, France). Marine Biology 91, 107-120.

Desrosiers, G., Savenkoff, C., Olivier, M., Stora, G., Juniper, K., Caron, A., Gagnè, J.-P., Legendre, L., Mulsow, S., Grant, J., Roy, S., Grehan, A., Scaps, P., Silverberg, N., Klein, B., Tremblay, J.E., Therriault, J.C., 2000. Trophic structure of macrobenthos in the Gulf of St. Lawrence and on the Scotian Shelf. Deep Sea Research, Part II: Topical Studies in Oceanography 47, 663-697.

Duffy, J.E., 2006. Biodiversity and functioning of seagrass ecosystems. Marine Ecology Progress Series 311, 233-250.

Emmerson, M.C., Solan, M., Emes, C., Paterson, D.M., Raffaelli, D., 2001. Consistent patterns and the idiosyncratic effects of biodiversity in marine ecosystems. Nature 411, 73-77.

FAO (Food and Agriculture Association), 2003. Fishery management. 2. The ecosystem approach to fisheries. FAO Technical Guidelines for Responsible Fisheries No. 4, Rome, Italy, 112 pp.

Fauchauld, K., Jumars, P.A., 1979. The diet of worms: a study of polychaete feeding guilds. Oceanography and Marine Biology: an Annual Review 17, 193-284.

Fonseca, J.C., Marques, J.C., Paiva, A.A., Freitas, A.M., Madeira, V.M.C., Jørgensen, S.E., 2000. Nuclear DNA in the determination of weighing factors to estimate exergy from organisms biomass. Ecological Modelling 126, 179-189.

Giordani Soika, A., Perin, G., 1974. L'inquinamento della Laguna di Venezia: studio delle modificazioni chimiche e del popolamento sottobasale dei sedimenti lagunari negli ultimi vent'anni. Bollettino del Museo Civico di Storia Naturale di Venezia 26, 25-67.

Gregory, T.R., 2005. Animal genome size database. Available from: http:// www.genomesize.com.

Holling, C.S., 1986. The resilience of terrestrial ecosystems, local surprise and global change. In: Clark, W.C., Munn, R.E. (Eds.), Sustainable Development of the Biosphere. Cambridge University Press, Cambridge, UK, pp. 292-317.

Holling, C.S., Schindler, D.W., Walker, B.W., Roughgarden, J., 1995. Biodiversity in the functioning of ecosystems: an ecological synthesis. In: Perrings, C.A., Mäler, K.-G., Folke, C., Holling, C.S., Jansson, B.-O. (Eds.), Biodiversity Loss. Economic and Ecological Issues. Cambridge University Press, Cambridge, UK, pp. 44-83.

Hyrenbach, K.D., Forney, K.A., Dayton, P.K., 2000. Marine protected areas and ocean basin management. Aquatic Conservation: Marine and Freshwater Ecosystems 10, 437-458.

Jackson, J., 2001. What was natural in the coastal oceans? Proceedings of the National Academy of Sciences 98, 5411-5418. 
Jackson, J., Kirby, M.X., Berger, W.H., Bjorndal, A., Botsford, L.W., Bourque, B.J., Bradbury, R.H., Cooke, R., Perlandson, J., Estes, J., Hughes, T.P., Kidwell, S., Lange, C., Lenihan, H.S., Pandolfi, J.M., Peterson, C.H., Steneck, R.S., Tegner, M.J., Warner, R.R., 2001. Historical overfishing and the recent collapse of coastal ecosystems. Science 293, 629-638.

Jørgensen, S.E., Nielsen, S.N., Mejer, H., 1995. Energy, environment, exergy and ecological modelling. Ecological Modelling 77, 99-109.

Leppäkoski, E., 1994. The Baltic and the Black Sea - seriously contaminated by nonindigenous species? In: Proceedings of the Conference and Workshop Nonindigenous Estuarine and Marine Organisms (NEMO), Seattle, Washington, April 1993. U.S. Department of Commerce, pp. 37-44.

Libralato, S., Pranovi, F., Torricelli, P., Raicevich, S., Da Ponte, F., Pastres, R., Mainardi, D., 2004. Ecological stages of the Venice Lagoon analysed using landing time series data. Journal of Marine Systems 51, 331-344.

Libralato, S., Torricelli, P., Pranovi, F., 2005. Exergy as ecosystem indicator: an application to the recovery process of marine benthic communities. Ecological Modelling 192, 571-585.

McArdle, B.H., Anderson, M.J., 2001. Fitting multivariate models to community data: a comment on distance-based redundancy analysis. Ecology 82, 290-297.

Marques, J.C., Jørgensen, S.E., 2002. Three selected ecological observations interpreted in terms of a thermodynamic hypothesis. Contribution to a general theoretical framework. Ecological Modelling 158, 213-221.

Marques, J.C., Pardal, M.A., Nielsen, S.N., Jørgensen, S.E., 1997. Analysis of the properties of exergy and biodiversity along an estuarine gradient of eutrophication. Ecological Modelling 102, 155-167.

Marques, J.C., Nielsen, S.N., Pardal, M.A., Jørgensen, S.E., 2003. Impact of eutrophication and river management within a framework of ecosystem theories. Ecological Modelling 166, 147-168.

MAV (Magistrato alle Acque di Venezia), 1992. Studio A3.16/II Composizione delle comunità biologiche connesse con le modifiche morfologiche - II fase, 123 pp.

Meysman, F.J.R., Boudreau, B.P., Middelburg, J.J., 2003. Relations between local, nonlocal, discrete and continuous models of bioturbation. Journal of Marine Research 61, 391-410.

NRC (National Research Council), 1995. Understanding Marine Biodiversity: A Research Agenda for the Nation. National Academy Press, Washington, DC, 114 pp.

Odum, E.P., 1969. The strategy of ecosystem development. Science 164, $262-270$.

Pastres, R., Solidoro, C., Ciavatta, S., Petrizzo, A., Cossarini, G., 2004. Longterm changes of inorganic nutrients in the Lagoon of Venice (Italy). Journal of Marine Systems 51, 179-189.

Pearson, T.H., 2001. Functional group ecology in soft-sediment marine benthos: the role of bioturbation. Oceanography and Marine Biology: an Annual Review 39, 233-267.

Pranovi, F., Giovanardi, O., 2000. Caratterizzazione della comunità macrobentonica in un'area del bacino sud della Laguna di Venezia. Bollettino del Museo Civico di Storia Naturale di Venezia 50, 213-224.

Pranovi, F., Lombardo, I., Giovanardi, O., Franceschini, G., 1999. Osservazioni sul popolamento macrobentonico della Valle di Brenta (Laguna di Venezia). Bollettino del Museo Civico di Storia Naturale di Venezia 48, 261-265.

Pranovi, F., Curiel, D., Rispondo, A., Marzocchi, M., Scattolin, M., 2000. Variations of the macro-benthic community in a seagrass transplanted area of the Venice lagoon. Scientia Marina 64, 303-310.

Pranovi, F., Libralato, S., Raicevich, S., Granzotto, A., Pastres, R., Giovanardi, O., 2003. Mechanical clam dredging in Venice Lagoon: effects on ecosystem stability evaluated with a trophic mass-balance model. Marine Biology 143, 393-403.

Pranovi, F., Da Ponte, F., Raicevich, S., Giovanardi, O., 2004. A multidisciplinary study of the immediate effects of mechanical clam-harvesting in the Venice Lagoon. ICES Journal of Marine Science 61, 43-52.
Pranovi, F., Franceschini, G., Casale, M., Zucchetta, M., Giovanardi, O., Torricelli, P., 2006. An ecological imbalance induced by a non-native species: the Manila clam in the Venice Lagoon. Biological Invasions 8, 595-609.

Provincia di Venezia, 2000. Piano per la gestione delle risorse alieutiche delle lagune della provincia di Venezia. Provincia di Venezia, Venice, 102 pp.

Raffaelli, D.G., 2006. Biodiversity and ecosystem functioning: issues of scale and trophic complexity. Marine Ecology Progress Series 311, 285-294.

Ravera, O., 2000. The Lagoon of Venice: the result of both natural factors and human influence. Journal of Limnology 59, 19-30.

Ruesink, J.L., Feist, B.E., Harvey, C.J., Hong, J.S., Trimble, A.C., Wisehart, L.M., 2006. Changes in productivity associated with four introduced species: ecosystem transformation of a 'pristine' estuary. Marine Ecology Progress Series 311, 203-215.

Sfriso, A., Facca, C., Ghetti, P.F., 2003. Temporal and spatial changes of macroalgae and phytoplankton in a Mediterranean coastal area: the Venice Lagoon as case study. Marine Environmental Research 56, 316-636.

Snelgrove, P.V.R., Blackburn, T.H., Hutchings, P., Alongi, D., Grassle, J.F., Hummel, H., King, G., Koike, I., Lambshead, P.J.D., Ramsing, N.B., Solis-Weiss, V., 1997. The importance of marine biodiversity in ecosystem processes. Ambio 26, 578-583.

Solan, M., Cardinale, B.J., Downing, A.L., Engelhardt, K.A.M., Ruesink, J.L., Srivastava, D.S., 2004. Extinction and ecosystem function in the marine benthos. Science 306, 1177-1180.

Sorokin, Y., Giovanardi, O., Pranovi, F., Sorokin, P., 1999. Restrictions needed in the farming of bivalve culture in the southern basin of the Lagoon of Venice. Hydrobiologia 400, 141-148.

Statzner, B., Bis, B., Doledec, S., Usseglio-Polatera, P., 2001. Perspectives for biomonitoring at large spatial scales: a unified measure for the functional composition of invertebrate communities in European running waters. Basic and Applied Ecology 2, 73-85.

Svirezhev, Y.M., 2000. Thermodynamics and ecology. Ecological Modelling $132,11-22$.

Tenore, K.R., Zajac, R.N., Terwin, J., Andrade, F., Blanton, J., Boynton, W., Carey, D., Diaz, R., Holland, A.F., López-Jamar, E., Montagna, P., Nichols, F., Rosenberg, R., Queiroga, H., Sprung, M., Whitlatch, R.B., 2006. Characterizing the role benthos plays in large coastal seas and estuaries: a modular approach. Journal of Experimental Marine Biology and Ecology 330, 392-402.

Tumbiolo, M.L., Downing, J., 1994. An empirical model for the prediction of secondary production in marine benthic invertebrate populations. Marine Ecology Progress Series 114, 165-174.

Vatova, A., 1940. Le zoocenosi della laguna di Venezia. Thalassia 10, 3-28. Wall, G., 1977. Exergy - A Useful Concept Within Resource Accounting. Report No. 77-42. Institute of Theoretical Physics, Chalmers University of Technology and University of Goteborg, Goteborg, Sweden, 58 pp.

Warwick, R.M., Ashman, C.M., Brown, A.R., Clarke, K.R., Dowell, B., Hart, B., Lewis, R.E., Shillabeer, N., Somerfield, P.J., Tapp, J.F., 2002. Inter-annual changes in the biodiversity and community structure of the macrobenthos in Tees Bay and the Tees estuary, UK, associated with local and regional environmental events. Marine Ecology Progress Series 234, 1-13.

Weslawski, J.M., Snelgrove, P.V.R., Levin, L.A., Austen, M.C., Kneib, R.T., Iliffe, T.M., Carey, J.R., Hawkins, S.J., Whitlatch, R.B., 2004. Marine sedimentary biota as providers of ecosystem goods and services. In: Wall, D.H. (Ed.), Sustaining Biodiversity and Ecosystem Services in Soils and Sediments. Island Press, Washington, pp. 73-98.

World Summit on Sustainable Development in Johannesburg, 2002. Available from: http://www.worldsummit2002.org/.

Zajac, R.N., 1999. Understanding the seafloor landscape in relation to assessing and managing impacts on coastal environments. In: Gray, J.S., Ambrose Jr., W., Szaniawska, A. (Eds.), Biogeochemical Cycling and Sediment Ecology. Kluwer Publishing, Dordrecht, pp. 211-227. 